\title{
Biometrical Analyses of a Sicilian Green Toad, Bufo siculus (Stöck et al. 2008), Population Living in Sicily (Italy)
}

\author{
Análisis Biométricos del Sapo Verde Siciliano, Bufo siculus \\ (Stöck et al. 2008), Población que Vive en Sicilia (Italia)
}

\author{
Mario Lo Valvo \& Gabriele Giacalone
}

LO VALVO, M. \& GIACALONE, G. Biometrical analyses of a Sicilian green toad, Bufo siculus (Stöck et al. 2008), population living in Sicily (Italy). Int. J. Morphol., 31(2):681-686, 2013.

SUMMARY: Morphometry structure of Sicilian green toad from the Nature Reserve "Monte Pellegrino" (north-western Sicily) was studied. A total of 666 individuals (354 males and 312 females) were captured in 2003 during reproduction period. Meaningful differences have statistically emerged among the two sexes and the body weight is the best parameter (up to $92 \%$ correct classification), followed by the length of the body (up to $90 \%$ correct classification). The simultaneous use of all the examined characters only increases of $1 \%$ the probability for correct discrimination of the sex. In comparison to the dimension of other green toad populations studied by other authors, the body size of this sicilian population results elevated, similar to that of Corsica and of Sardinia. It is possible that the high dimension of the Sicilian population is the result of low competition with other amphibians species and/or to the absence of a winter latency.

KEY WORDS: Bufo siculus; Biometrical analysis; Sicily.

\section{INTRODUCTION}

Recent taxonomic studies have divided the green toad (Bufo viridis), considered as the only euro-Central AsianNorth African species, in different species (Stöck et al., 2006, 2008; Batista et al., 2006). These studies shows for Italy the presence of four specific taxa: Bufo viridis Laurenti, 1869, living in a limited portion of north-eastern of mainland Italy; Bufo balearicus Boettger, 1880, living on the remaining part of the mainland, on the Sardinia island and on the northeastern Sicily island; Bufo siculus Stöck et al. (2008), living remaining in this part of Sicily, including some smaller islands; Bufo boulengeri Lataste, 1879, living, for Italy, exclusively on the Lampedusa island.

The Sicilian green toad, Bufo siculus Stöck et al. (2008), is a widespread monotipic species, endemic to Sicily, as well as Favignana Island and Ustica Island. This species is fairly common and the majority of the populations live between the sea level and 800 meters above sea level.

The ecology, biology and biometrical characteristics of Bufo viridis subgroup in continental and peninsular Italian populations is fairly well known (Zugolaro et al., 1993;
Giacoma, 2000; Giacoma et al., 2000; Laoretti et al., 2000; Rosso et al., 2000; Malavasi, 2002), while information about the insular populations is limited to those living in Corsica and Sardinia (Castellano \& Giacoma, 1998; Giacoma).

For some years we have been studying the Sicilian green toad in Sicily, isolated, and about which we know very little. In this study we analyze some aspects of morphometry of a population reproductive in the north-west of Sicily and we report the results about the comparison of the body size among two sexes and about the comparison of this population with other insular and continental populations including the green toad subgroup.

Study area. The study area is situated in the Nature reserve "Monte Pellegrino" (north-western, Sicily) and the place of reproduction is a temporary pond ("Gorgo di S. Rosalia"), at an altitude of about $380 \mathrm{~m}$ above sea level, and set between two artificial reforestations of eucalyptus (Eucalyptus spp.) and pine (Pinus spp.). The pond, the only one in which the whole population of Mount Pellegrino reproduces, presents a subelliptic shape with a length of 55 meters, a maximum 
width of 40 meters and a maximum depth of 2.1 meters. The dimensions of this pond vary according to the quantity of rain water, which can vary considerably from one year to another, so the above mentioned values are seldom reached (Naselli Flores et al., 2002).

On the whole the hydric body is characterized by high nutritional levels and rather low $\mathrm{pH}$ values, due to the production of the ulmin originating from the length of decomposition of the forest floor of pine needles and eucalyptus leaves, and bicarbonate alkaline waters, connected with the calcareous features of the soil (Naselli Flores et al., 2002).

\section{MATERIAL AND METHOD}

From January to March 2003, during their reproductive period, the measurements of 666 specimens (354 males and 312 females) of Sicilian green toad were taken. Each specimen was measured for biometric variables with digital callipers (to the tenth of a millimetre) and digital balance (measurement in grams). For body size characterization we used the following morphometric variables (Fig. 1): body length (SVL), distance between the top of the head and the eyes (DTE), distance between the eyes (DEY), head width (WHE), radio-ulna length (RUL), tibia length (TBL), tarsus length (TRL), distance between the top of the first and second toes of the back foot (DFS) and body weight (BW). During the breeding period, thumb pads of the males are helpful to discriminate the two sexes, while the photo-identification, used for the estimation of population numerosity, has avoided the measurement of specimens already captured.

The data collected was used for the calculation of statistical description while the univaried statistics (t-test) was used to analyse the dimensional differences between the two sexes. The possible differences in shape between the sexes was checked by using the Principal Component Analysis (PCA), applied to the correlation matrix, which eliminates the dimentional effect in the components that follow the first component (Chessel \& Auda, 1986; Camussi et al., 1991). Finally, the Discriminant Analysis (DA) was used, which permits the selection of the variables considered useful for determining sex and produces linear functions (predictive equations) through the combination of the biometrical variables that give the maximum variability among groups (Legendre \& Legendre, 1979; Digby \& Kempton, 1987; Sokal \& Rohlf, 1989) and allows their use to determine the sex of any toad measured out of breeding, when the sex is unknown.

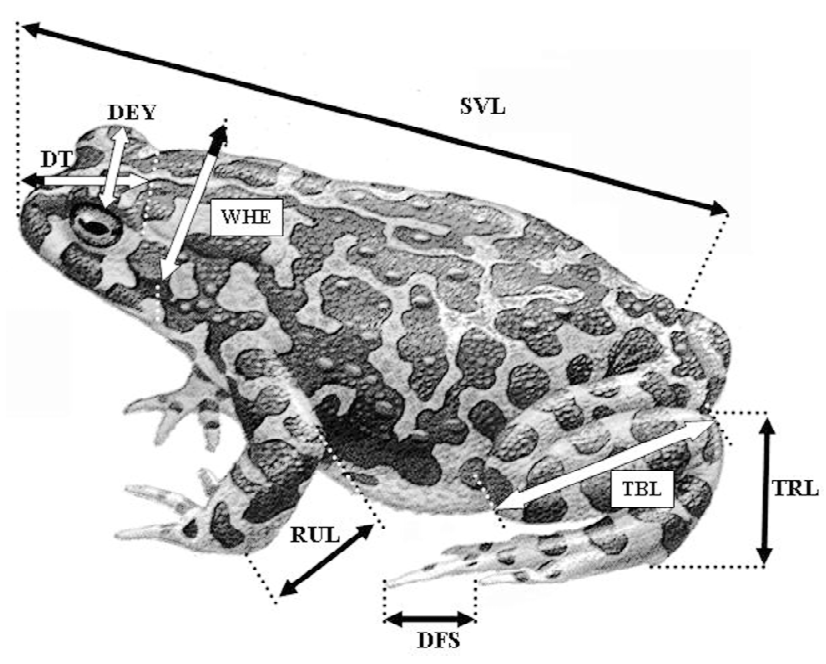

Fig. 1. Body measurements of Green toad. For abbreviations see Material and Method.

\section{RESULTS}

In Table I we report the mean, confidence interval (95\%) and range of the nine biometrical variables analysed, according to sex. T-test show sexual dimorphism of the body measurements (all $\mathrm{p}$ values $<0.001$ ).

The scatterplot of scores of the first two principal components (Fig. 2), obtained by the PCA on the correlation matrix, together with the equiprobability ellipses at 95\% (Lagonegro \& Feoli, 1985), show a certain distinction among the clusters relative to the two sexes. Apart from the DFS variable, correlated with the factorial axis PC2, the other variables are linked to one another and the factorial axis PC1, which is considered the main summarizes of the toad's body size. The eigenvalues connected with the components following the first one result very low and so do not show differences in shape. Table II displays the coefficents of the first two extract eigenvectors and the relative percentage of the displayed variance.

The stepwise discriminant function analysis confirms the difference in biometric values, and only five (SVL, DEY, TBL, DFS, BW) out of nine body proportion characters contribute to the between-sex discrimination $(\mathrm{r}$ $=0.85 ;$ Wilks'l $=0.273 ; \mathrm{F}(8.656)=194.2 ; \mathrm{P}<0.001)$ and BW weight and SVL have the absolute largest standardized coefficients. Table III reports the discriminant functions, standardized and not, by which the percentage of the correct classification is $94.7 \%$. 
Table I. Means, standard deviations and ranges of males and females upon nine body characters of Green toad in Sicily.

\begin{tabular}{lccc}
\hline & & $\begin{array}{c}\text { Males } \\
(\mathbf{n}=\mathbf{3 5 4})\end{array}$ & $\begin{array}{c}\text { Females } \\
(\mathbf{n}=\mathbf{3 1 2})\end{array}$ \\
\hline SVL $(\mathrm{mm})$ & Mean \pm C.I. & $73.9 \pm 0.52$ & $86.7 \pm 0.57$ \\
& Range & $58.6-86.6$ & $71.2-99.7$ \\
DTE $(\mathrm{mm})$ & Mean \pm C.I. & $15.2 \pm 0.15$ & $16.2 \pm 0.17$ \\
& Range & $11.7-19.6$ & $11.1-20.3$ \\
DEY $(\mathrm{mm})$ & Mean \pm C.I. & $18.9 \pm 0.15$ & $21.0 \pm 0.17$ \\
& Range & $14.6-22.2$ & $16.8-27.9$ \\
WHE $(\mathrm{mm})$ & Mean \pm C.I. & $25.7 \pm 0.22$ & $28.8 \pm 0.28$ \\
& Range & $14.9-31.3$ & $20.6-35.4$ \\
RUL $(\mathrm{mm})$ & Mean \pm C.I. & $19.9 \pm 0.19$ & $21.6 \pm 0.18$ \\
TBL $(\mathrm{mm})$ & Range & $13.6-25.5$ & $17.8-27.2$ \\
& Mean \pm C.I. & $27.8 \pm 0.22$ & $29.7 \pm 0.24$ \\
TRL $(\mathrm{mm})$ & Range & $18.1-32.8$ & $18.6-34.6$ \\
& Mean \pm C.I. & $19.2 \pm 0.17$ & $20.9 \pm 0.16$ \\
DFS $(\mathrm{mm})$ & Range & $11.5-27.7$ & $16.2-28.7$ \\
& Mean \pm C.I. & $12.1 \pm 0.18$ & $12.5 \pm 0.17$ \\
BW $(\mathrm{g})$ & Range & $7.8-17.0$ & $7.0-16.9$ \\
& Mean \pm C.I. & $49.3 \pm 0.99$ & $82.4 \pm 1.47$ \\
& Range & $22-81$ & $50-116$ \\
\hline
\end{tabular}

Table II. Coefficients of the first and second eigenvector and relative $\%$ of variance obtained by Principal Components Analysis upon nine body characters of Green toads.

\begin{tabular}{lcc}
\hline & PC1 & PC2 \\
\hline SVL & -0.90 & 0.13 \\
DTE & -0.51 & -0.51 \\
DEY & -0.82 & 0.11 \\
WHE & -0.80 & 0.35 \\
RUL & -0.81 & 0.04 \\
TBL & -0.74 & 0.21 \\
TRL & -0.77 & -0.14 \\
DFS & -0.37 & -0.71 \\
BW & -0.83 & -0.05 \\
Eigen value & 5.00 & 0.98 \\
\% variance & 55.6 & 10.9 \\
\hline
\end{tabular}

Table III. Standardized and unstandardized discriminant function $\mathrm{SD}=$ discriminant score.

\begin{tabular}{lcc}
\hline & Unstandardized & Standardized \\
\hline SVL & -0.11 & -0.54 \\
DEY & -0.12 & -0.17 \\
RUL & 0.10 & 0.17 \\
TBL & 0.09 & 0.22 \\
DFS & 0.11 & 0.18 \\
BW & -0.06 & -0.70 \\
Constant & 8.77 &
\end{tabular}

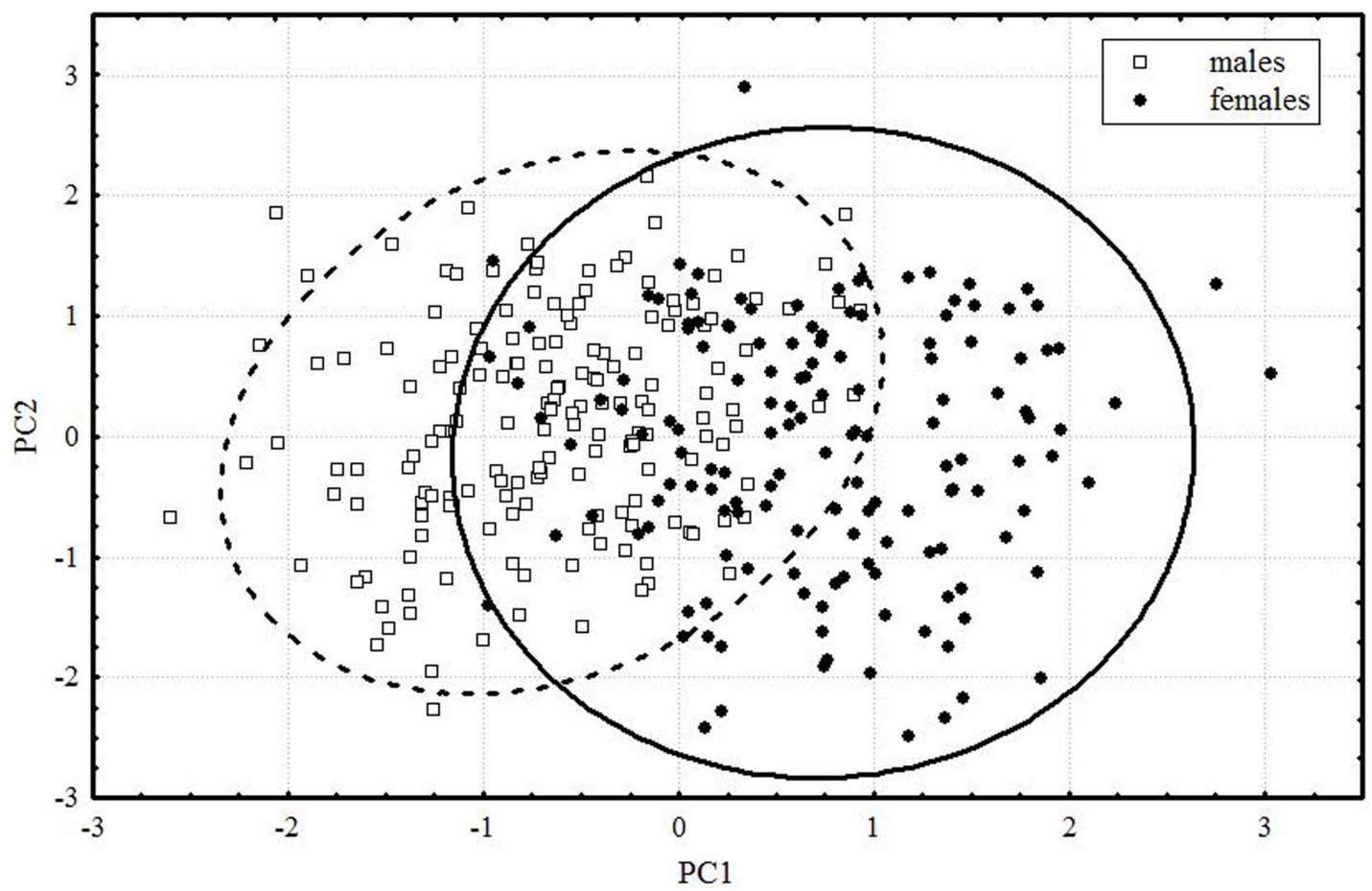

Fig. 2. Plot of scores of male and female specimens of Green toad on the first two principal components axes, and $95 \%$ probability ellipse. 


\section{DISCUSSION}

Generally speaking the anura female is bigger size than the male (Shine, 1979). This has been interpreted with the higher fertililty correlated with body size in the female and a lower energetic strength in the male in populations that breed explosively (Woolbright, 1983; Halliday \& Verrell, 1988). As for the Green toad the difference in the body size between males and females, resulted statistically significant in "Monte Pellegrino", is considered more or less variable according to the population. Giacoma observed statistically significant differences between the two sexes in populations with a large body size, while, in populations with gradually smaller dimensions, the differences result less evident until they are not significant.

From the results obtained by the discriminant analysis it is evident that weight represents the biometric variable with the best capacity of sexual discrimination. It is probable that this feature is due in particular to the fact that it is easier to distinguish the two sexes during the reproductive period, when the female shows a physiological increase in body weight, related to the production of the eggs, which could accentuate the difference with the male.

The contemporary use of all examined variables increases the probability of a correct sexual classification by only $1 \%$. Therefore if not used for other aims, the survey of the numerous biometric variables for sex determination apart from during the reproductive period, is considered useless.

The body size of the specimens of the population living in Mount Pellegrino results among the highest for this species. In particular the total length values (SVL) and the weight values (BW) are bigger $(\mathrm{p}<0.001)$ than the ones of the continental population (Zugolaro et al.; Karakousis \& Kyriakopoulou-Sklavounou, 1995; Castellano \& Giacoma; Giacoma; Laoretti et al.; Rosso et al.), while they are very similar to the ones in Sardinia (Castellano \& Giacoma; Giacoma), and above all in Corsica (Castellano \& Giacoma), an island on which some authors claim that the subspecified taxon $B$. viridis balearicus might be present (Duguet \& Melki, 2003). Our data would confirm the biggest size among the insular population (already noticed by Castellano \& Giacoma), and they present the lack of any climate variation linked to latitude, hypothesized by Camerano (1904) regarding the Italian populations, by Nevo (1972) regarding the Israeli populations and by Pisanets \& Scerbac (1979) for some Asian populations. These authors have made the hypothesis that in areas with a drier climate and at lower latitude a bigger size favored survival. It has been seen that several factors of climatic, ecological and trophic type influence the difference in size of the green toad. (Jörgensen, 1984; Giacoma et al., 1997; Castellano \& Giacoma; Laoretti et al.).

In the case of the population living in "Monte Pellegrino", the bigger size, if not attributable to taxonomic differences (Batista et al., 2006; Stöck et al., 2006, 2008), could depend on biological and ecological factors that influence the average age of the population with which size seems to be correlated (King, 1989). This higher average age could in turn depend both on the steady presence of this population in this area and on the low mortality of the adult, due to both to the absence of natural predators and on the lack of competition with the other species (Lomolino, 1985). In fact, the target area is home to another amphibian species, the Painted frog, Discoglossus pictus Otth, 1837, present with a small population.

Finally, the hypothesis that, differently from what occurs in most Amphibian populations where body growth decreases in winter, should not be ignored (Duellman \& Trueb, 1986; Hallyday \& Verrell), the big body size in the area researched could be influenced by the constant body growth, due to the lack of a winter latency (Lo Valvo \& Giacalone, 2004).

\section{ACKNOWLEDGEMENTS}

We thank Rangers d'Italia, Management Board of the "Monte Pellegrino" Nature Reserve, and expecially to the former director Dr. Salvatore Livreri Console for the research authorisations and for the scientific and logistic collaboration. Moreover, very many thanks to everybody who helped us in the field, in particular M. Tirrito, R. Guccione, M. Scalisi, A. Cacace, L. Piraino, L. Di Piazza, A. La Scala e E. Oliveri.

LO VALVO, M. \& GIACALONE, G. Análisis biométricos del sapo verde siciliano, Bufo siculus (Stöck et al. 2008), población que vive en Sicilia (Italia). Int. J. Morphol., 31(2):681-686, 2013.

RESUMEN: Se realizó un estudio morfométrico de la estructura del sapo verde siciliano de la Reserva Natural "Monte Pellegrino" (norte-oeste de Sicilia). Un total de 666 individuos (354 machos y 312 hembras) fueron capturados desde el año $2003 \mathrm{du}-$ rante la época de reproducción. Se encontraron diferencias estadísticamente significativas entre los dos sexos, donde el peso corporal fue el mejor parámetro (hasta 92\% de clasificación co- 
rrecta), seguido por la longitud corporal (hasta $90 \%$ de clasificación correcta). El uso simultáneo de todos los caracteres examinados solo aumentó un $1 \%$ la probabilidad de una correcta discriminación del sexo. En comparación con la dimensión de otras poblaciones de sapos verdes estudiados por otros autores, el tamaño del cuerpo de esta población siciliana resulta elevado, similar a las poblaciones de Córcega y Cerdeña. Es posible que la gran dimensión de la población siciliana pueda deberse al bajo nivel de competencia con anfibios otras especies y/o a la ausencia de una latencia de invierno.

\section{PALABRAS CLAVE: Bufo siculus; Análisis biométrico;} Sicilia.

\section{REFERENCES}

Batista, V.; Carranza, S.; Carretero, M. A. \& Harris, D. J. Genetic variation within Bufo viridis: evidence from mitochondrial $12 \mathrm{~S}$ and 16S rRNA DNA sequences. Butll. Soc. Cat. Herp., 17:2433, 2006.

Camerano, L. Ricerche intorno alla variazione del Bufo viridis Laur., del Bufo mauritanicus Schlegel e del Bufo regularis Reuss. Mem. Reale Accad. Sci. Torino, 54(2):183-265, 1904.

Camussi, A.; Möller, F.; Ottaviano, E. \& Sari Gorla, M. Metodi statistici per la sperimentazione biologica. Bologna, Zanichelli, 1991.

Castellano, S. \& Giacoma, C. Morphological variation of the green toad Bufo viridis, in Italy: a test of causation. J. Herpetol., 32(4):540-50, 1998.

Chessel, D. \& Auda, Y. Analyse en composantes principales sur matrice de correélation. (ACPN). Institut d'Analyse des Systemes Biologiques et Socio-Economiques. Universitè de Lion, 1986. pp.1-39.

Digby, P. G. N. \& Kempton, R. A. Multivariate analysis of ecological communities. London, Chapman and Hall, 1987.

Duellman, W. E. \& Trueb, L. Biology of Amphibians. New York, McGraw Hill Book Company, 1986.

Duguet, R. \& Melki, F. Les Amphibiens de France, Belgique et Luxembourg. Mèze (France), Collection Parthénope, Biotope, 2003. p.400.

Giacoma, C.; Zugolaro, C. \& Beani, L. The advertisement call of the green toad (Bufo viridis): consistency, variability and role in mate choice. Herpetologica, 53:454-64, 1997.

Giacoma, C. Struttura di popolazione. Riv. Idrobiol., 38:251-65, 2000.

Giacoma, C.; Zugolaro, C. \& Kozar, F. Temporal spacing of breeding activity in the green toad, Bufo viridis. In: Giacoma, C. (ed.).
Atti I Congresso Nazionale della Societas Herpetologica Italica. Torino, Mus. reg. Sci. nat., 2000. pp.101-8.

Halliday, T. R. \& Verrell, P. A. Body size and age in Amphibian and Reptiles. J. Herpetol., 22(3):253-65, 1988.

Jörgensen, C. B. Ovarian functional patterns in Baltic and Mediterranean populations of a temperate zone anuran, the toad Bufo viridis. Oikos, 43:309-21, 1984.

Karakousis, Y. \& Kyriakopoulou-Sklavounou, P. Genetic and morphological differentiation among populations of the Green toad Bufo viridis from Northern Greece. Biochem. Syst. Ecol., 23(1):39-45, 1995.

King, R. B. Body size variation among island and mainland snake populations. Herpetologica, 45:84-8, 1989.

Lagonegro, M. \& Feoli, E. The use of ellipses of equal concentration to analyse ordination vegetation patterns. Stud. Geobot., 5:143165, 1985.

Laoretti, F.; Castellano, S. \& Giacoma, C. Struttura e dinamica stagionale di alcune popolazioni di rospo smeraldino (Bufo viridis) del Savonese. In: Giacoma, C. (ed.). Atti I Congresso Nazionale della Societas Herpetologica Italica. Torino, Mus. Reg. Sci. Nat., 2000. pp.109-16.

Legendre, L. \& Legendre, P. Ecologie numerique. Vol. II. Paris, Masson, 1979.

Lomolino, M. V. Body size of mammals on island rule re-examined. Amer. Natur., 125(2):310-6, 1985.

Lo Valvo, M. \& Giacalone, G. Osservazioni preliminary sulla fenologia riproduttiva della popolazione di Rospo smeraldino, Bufo viridis Laurenti, 1768, della Riserva Naturale di Monte Pellegrino (Palermo). Ann. Museo Civ. St. Nat. Ferrara, 6:85-9, 2004.

Malavasi, D. Note ed osservazioni sulla erpetocenosi di agroecosistemi ad agricoltura intensiva della bassa pianura modenese. Natura Modenese, 6:65-74, 2002.

Naselli Flores, L.; Barone, R.; Pasta, S. \& Livreri Console, S. Il Gorgo di Santa Rosalia. Studio limnologico e prospettive di conservazione. Palermo, Eurografica, 2002.

Nevo, E. Climatic adaptation in size of the green toad, Bufo viridis. Israel J. Med. Sci., 8:1010, 1972.

Pisanets, E. \& Scerbac, N. Sistematica zelenih jab fauni USSR (Amphibia, Anura, Bufo). Veatnic Zoologhii, 4:11-6, 1979.

Rosso, A.; Doglio, S.; Bovero, S.; Castellano, S. \& Giacoma, C. Struttura di età di tre popolazioni di rospo smeraldino (Bufo viridis) in Piemonte. In: Giacoma, C. (ed.). Atti I Congresso Nazionale della Societas Herpetologica Italica. Torino, Mus. Reg. Sci. Nat., 2000. pp.459-66. 
Shine, R. Sexual selection and sexual dimorphism in the Amphibia. Copeia, 79:297-306, 1979.

Sokal, R. R. \& Rohlf, F. J. Biometry. New York, W. H. Freeman, 1989.

Stöck, M.; Moritz, C.; Hickerson, M.; Frynta, D.; Dujsebayeva, T.; Eremchenko, V.; et al. Evolution of mitochondrial relationships and biogeography of Paleartic green toads (Bufo viridis subgroup) with insights in their genomic plasticity. Mol. Phylogenet. Evol., 41(3):663-89, 2006.

Stöck, M.; Sicilia, A.; Belfiore, N.; Buckley, D.; Lo Brutto, S.; Lo Valvo, M.; et al. Post-Messinian evolutionary relationships across the Sicilian channel: Mitochondrial and nuclear markers link a new green toad from Sicily to African relatives. $B M C$ Evol. Biol., 8:56, 2008.

Woolbright, L. L. Sexual selection and size dimorphism in Anuran amphibia. Am. Nat., 121:110-9, 1983.

Zugolaro, C.; Giacoma, C. \& Kozar, F. The population structure of Bufo viridis. Suppl. Ric. Biol. Selvaggina, XXI:713-20, 1993.
Correspondence to:
Mario Lo Valvo

Dip. Scienze e Tecnologie Biologiche,

Chimiche, Farmaceutiche

University of Palermo

Via Archirafi 18,

I-90123 Palermo

ITALY

Email: mario.lovalvo@unipa.it

Received: 26-12-2012

Accepted: 27-02-2013 